\title{
USE OF PHYTOREMEDIATION TECHNIQUES FOR ELIMINATION OF LEAD FROM POLLUTED SOILS
}

\author{
ALŽBETA HEGEDÜSOVÁ ${ }^{1}$, SILVIA JAKABOVÁ ${ }^{1}$, ANDREA \\ VARGOVÁ $^{1}$, ONDREJ HEGEDÜS ${ }^{2}$, TÍMEA JUDIT PERNYESZI ${ }^{3}$ \\ ${ }^{1}$ Department of Chemistry, Constantine the Philosopher University in Nitra, \\ Tr. A. Hlinku 1, Nitra, SK- 949 01, SlovakRepublic (ahegedusova@ukf.sk, \\ sjakabova@ukf.sk,avargova@ukf.sk) \\ ${ }^{2}$ Regional Authority of Public Health in Nitra, Štefánikova 58, Nitra, SK- 949 63, \\ SlovakRepublic (nr.hegedus@uvzsr.sk) \\ ${ }^{3}$ Department of Analytical and Environmental Chemistry University of Pécs, \\ Ifjúság u. 6, Pécs, HU-7624, Hungary (ptimea@ttk.pte.hu)
}

\begin{abstract}
The effect of chelating agent - EDTA (ethylene-diamine-tetra-acetic acid) was used for induced phytoextraction to increase intensity of lead transfer from roots to aboveground parts of garden pea. Pot experiments with contaminated soil substrata $\left(50 \mathrm{mg} \mathrm{Pb} \cdot \mathrm{kg}^{-1}\right.$ and $\left.100 \mathrm{mg} \mathrm{Pb} \cdot \mathrm{kg}^{-1}\right)$ were established for experimental purposes in growth chamber. The results showed that application of 5 and 10 mmol EDTA.kg ${ }^{-1}$ to experimental variants with $100 \mathrm{mg} \mathrm{Pb} \cdot \mathrm{kg}^{-1}$ doubled the increase of lead uptake by pea roots in comparison with variants without EDTA addition, which was statistically confirmed. Intensive lead transfer was observed from roots to aboveground parts of pea after application of 5 and 10 mmol EDTA. $\mathrm{kg}^{-1}$ in variant with $50 \mathrm{mg} \mathrm{Pb} \cdot \mathrm{kg}^{-1}$ (40-fold increase), as well as in variant with $100 \mathrm{mg} \mathrm{Pb} \mathrm{kg}^{-1}$ (17-fold increase). The results showed that induced phytoextraction can improve the mobility of lead from soil to plant roots. Application of 5 mmol EDTA. $\mathrm{kg}^{-1}$ resulted to 40 -fold increase of lead transfer to green plant parts, despite the fact, that garden pea does not belong to conventional metal hyperaccumulating plant species. Following the results, pea could be used for decontamination of arable soil. The optimal EDTA concentration seems to be $5 \mathrm{mmol} . \mathrm{kg}^{-1}$. Therefore, application of 10 mmol EDTA. $\mathrm{kg}^{-1}$ decreased root mass about $55 \%$, which resulted to decrease the intensity of lead uptake.
\end{abstract}

Key words: induced phytoextraction, EDTA, lead, garden pea

\section{Introduction}

The territory of Slovakia belongs to long term polluting areas with transfer of contaminants from large industrial and power plant complexes with regional effects. These negative effects affect an extraordinary heterogenous soil cover and increase the content of risk elements to amounts exceeding their limits.

Accumulation of risk elements in soils affects its ability to produce hygienically unobjectionable foodstuffs, which applies especially for the content of heavy metals with a high degree of biotoxicity from various sources (HEGEDÜSOVÁ et al., 2000). Decontamination of areas, polluted with toxic metals, presents one of very important research topics and cleaning of the areas by conventionally used physico-chemical methods is financially very expensive and often non-ecologic. Modern decontamination technologies, generally called phytoremediation offer possibilities of removing heavy metals from soils (HUANG and CUNNINGHAM, 1996; LASAT, 2002; SIMON et al., 2003). The most often used phytoremediation techniques are especially phytoextraction and phytostabilitation. 
During the process of phytoextraction, plants absorb contaminants from soil through the root system and store them mainly in the green biomass and partially in root biomass. Application of chelating agents increases the bioavailability of the elements, which is known as an induced phytoextraction process. The most effective is using the plant species with larger biomass production (McGRATH et al., 2002). Obtained biomass is processed by several different techniques including microbiological (composting), thermic (ashing or combustion), or chemical (extraction) ones. Some of plants species, called hyperaccumulators, bind the metals in high amounts, and therefore, they are used in phytoremediation. Tolerance of plants to heavy metals can be explained by binding of metal to cell wall, membrane tolerance to metals, active transport of metals in plant cells, presence of metal-tolerant enzymes, accumulation of metals in vacuole and chelatation of metals with organic or inorganic ligands.

Lead does not belong to essential elements; moreover, it is highly toxic for animals and humans. Similarly to other heavy metals, ions of lead are also potential cancerogenic agents. Lead disturbs intermediate metabolism, inhibits the exchange of saccharides in nerve tissue, affects the changes in metabolism of porphyrins and influences the inhibition of homeostasis. It mainly interferes with enzymes on their sulfhydryl groups. The highest risk of intake and retention of this xenobiotic element is from foodstuff intake, therefore approximately $60 \%$ of lead in human organism is ingested and $30 \%$ comes from inhalation (KAFKA and PUNČOCHÁŘOVÁ, 2002).

Common source of lead is soil. The content of lead in main soil types in Slovakia varies in wide interval between 10 and $60 \mathrm{mgPb} \cdot \mathrm{kg}^{-1}$. Natural values of $\mathrm{Pb}$ in soil rise after accumulation of dust around roads and from wet deposition after rainfalls. In soil, degradation by microorganisms does not occur, because contact with oxygen leads to oxidation (FODOR, 2003; FODOR et al., 1996; GRČMAN et al., 2003).

The aim of this work was to follow the effect of selected chelating agent - EDTA (ethylene-diamine-tetra-acetic acid) within decontamination of soil to increase transfer of lead from model contamined soil to aboveground parts of garden pea (Pisum sativum L.) using the technique of induced phytoextraction.

\section{Materials and methods}

\subsection{Plant material}

Pot experiment was established with garden pea (Pisum sativum L., variety Oskar, very early, marrowfat). From nutritional aspect, peas are well known for being a rich source of highly bioavailable protein. Composition of the proteins is similar to proteins of animal origin. Ions of heavy metals usually attack tiol-groups, and also binding on carboxyl or amino groups of amino acids occurs in pea proteins. This could explain why pea has higher uptake of metals than cereals. N-compounds exceed $90 \%$ in pea; moreover, main fraction present globulins $(45-60 \%)$ and other fractions (albumins, insoluble proteins and non-protein fraction) present approximately $15-20 \%$ of all nitrogen. Content of proteins varies in dependence on variety properties, soil, nutrition, climatic conditions and level of maturity. Pea seeds are important source of vitamins 
C, E and B group, derivatives of folic acid, called folates, and macro elements like phosphorus, potassium, magnesium, and calcium. Pea is also interesting from the aspect of water soluble or non soluble fibre.

\subsection{Pot experiments with induced phytoextraction}

Model pot experiments were realized in nine experimental variants in growth chamber with controlled condition at the Department of botany and genetics Constantine the Philosopher University in Nitra. Growing medium was clean soil substrata in an amount $1000 \mathrm{~g}$ in each pot. Lead solution was applied in two concentrations (50 and $100 \mathrm{mg} \mathrm{Pb} \cdot \mathrm{kg}^{-1}$ ) by spraying of soil 4 weeks before sowing. Garden pea was sowed directly to pots in amount 20 seeds per pot. Growing conditions were following: air temperature $20{ }^{\circ} \mathrm{C}$, air humidity $60-70 \%$, soil humidity $75 \%$. Light was set to $12 \mathrm{~h}$ of light and $12 \mathrm{~h}$ of darkness, intensity of radiation was max. $50000 \mathrm{~lx}$ ).

In the sixth and seventh week of growth, chelating agent EDTA was applied as the solutions with the total addition 5 and $10 \mathrm{mmol} \cdot \mathrm{kg}^{-1}$. After eight weeks of growth all experimental plants were harvested and submitted to analysis.

\subsection{Sample preparation and determination of lead by ET-AAS technique}

Dry and homogenized plant samples in amount $1 \mathrm{~g}$ were wet digested in vessels ZA-1 with digesting mixture $1 \mathrm{~cm}^{3}$ deionized water, $2 \mathrm{~cm}^{3} \mathrm{H}_{2} \mathrm{O}_{2}$ and $5 \mathrm{~cm}^{3} \mathrm{HNO}_{3}$. Soil extracts in were prepared according to standard STN ISO 11466:2001.

Solutions of roots, aboveground plant parts and soil extracts were submitted to quantitative determination of lead using the method ET-AAS. Determination was done on atomic absorption spectrometer SpectrAA240FS (Varian, Mulgrave Virginia, Australia). The technique requires lead hollow cathode lamp to operate at a wavelength of $217.0 \mathrm{~nm}$ with a slit width set to $1.0 \mathrm{~nm}$ and an electrodeless discharge lamp set at $5 \mathrm{~mA}$ current. Injected sample volume was $10 \mu \mathrm{l}$ and palladium matrix modifier $\mathrm{Pb}\left(\mathrm{NO}_{3}\right)_{2}$ with concentration 0.1 mol.dm ${ }^{-3}$ digested in $0.1 \% \mathrm{HNO}_{3}$ and ascorbic acid (1\%) were used as modifiers.

\subsection{Evaluation of results}

Evaluation of the results was done with the method of calibration curve. The results were statistically evaluated using the single-factor analysis of variance and Tukey $b$ test in SPSS program.

\section{Results and discussion}

Effect of chelating agent EDTA to enhance lead uptake from soil to plant and metal transfer in the plant was followed. Model concentrations of lead were proposed according to results of soil monitoring on southern Slovakia (HEGEDÜSOVÁ et al., 2000). In variants with $\mathrm{Pb}$ addition $50 \mathrm{mg} \mathrm{Pb} \cdot \mathrm{kg}^{-1}$ and $100 \mathrm{mg} \mathrm{Pb} \cdot \mathrm{kg}^{-1}$ without EDTA treatment pea roots accumulated lead in amount $0.22 \mathrm{mg} \mathrm{Pb} . \mathrm{kg}^{-1}$ and $0.27 \mathrm{mg} \mathrm{Pb} . \mathrm{kg}^{-1}$ 
respectively. Transfer of lead did not continue from roots to aboveground parts of plant in variant without application of EDTA. On the other hand, addition of chelating agent (EDTA) enhanced the content of the metal in all plant tissues in comparison to variant without EDTA treatment. Pb content in pea roots from pots with $50 \mathrm{mg} \mathrm{Pb} . \mathrm{kg}^{-1}$ increased about 30\% (1.3-fold) after application 5 mmol EDTA. $\mathrm{kg}^{-1}$.

Non-significant enhancement of $\mathrm{Pb}$ was found after application of $10 \mathrm{mmol}$ EDTA. $\mathrm{kg}^{-1}$ in comparison with EDTA-nontreated variant (Table 1, Fig.1). Additions of EDTA resulted to statistically significant increase of lead transfer from soil to pea roots within the soil treatment with $100 \mathrm{mg} \mathrm{Pb} \cdot \mathrm{kg}^{-1}$ and 5 mmol EDTA. $\mathrm{kg}^{-1}$. The increase presented $150 \%$ in comparison with EDTA non treated variant. $100 \%$ increase of $\mathrm{Pb}$ content was found in variant with application $100 \mathrm{mg} \mathrm{Pb} \cdot \mathrm{kg}^{-1}$ and 10 mmol EDTA. $\mathrm{kg}^{-1}$ compared with variant without chelate (Table 1, Fig. 2).

Statistically significant increase of lead in aboveground plant parts of pea was also found in variants with $50 \mathrm{mg}$. $\mathrm{Pb} \mathrm{kg}^{-1}$ in combination with EDTA treatment. Application of 5 and 10 mmol EDTA. $\mathrm{kg}^{-1}$ resulted to 44-fold and 36-fold increase of $\mathrm{Pb}$ respectively. Lead content in aboveground parts rised approximately 18-times in variant with $100 \mathrm{mg} \mathrm{Pb} . \mathrm{kg}^{-1}$ in combination with two applied concentrations of chelate (Table 1, Fig.1, Fig.2).

There is an assumption that root exudes in a mixture of selected plant species played an important role in the process of metal dissolving in soil and make easier the uptake of metals by pea roots. LUO et al. (2008) experimentally proved enhancement of metal uptake (in pea, placed in mixed culture with barley. Concentrations of $\mathrm{Pb}, \mathrm{Cu}$, $\mathrm{Zn}, \mathrm{Cd}$ and $\mathrm{Fe}$ in the shoots were higher than in the case of growing pea in isolation. These results presented the evidence that natural chelates, produced by plants themselves, enhance the bioavailability of heavy metals in soil solution and support their uptake by plants.

Table 1. Content of lead in roots and aboveground parts of garden pea in dependence on soil treatment by lead and EDTA (pot experiments in growth chamber, Nitra, 2008).

\begin{tabular}{|c|c|c|c|c|c|c|}
\hline \multirow{3}{*}{$\begin{array}{c}\text { Variant } \\
\text { Pb/EDTA }\end{array}$} & \multicolumn{6}{|c|}{ Content of $\mathbf{P b}\left[\mathrm{mg} \cdot \mathrm{kg}^{-1}\right]$} \\
\hline & \multicolumn{3}{|c|}{ roots } & \multicolumn{3}{|c|}{ aboveground parts } \\
\hline & $\mathbf{x}_{\min }$ & $\mathbf{x}_{\mathrm{m}}$ & $\mathbf{x}_{\max }$ & $\mathbf{x}_{\min }$ & $\mathbf{x}_{\mathrm{m}}$ & $\mathbf{x}_{\max }$ \\
\hline C & 0.042 & $0.05^{\mathrm{a}}$ & 0.05 & 0.02 & $0.03^{\mathrm{a}}$ & 0.04 \\
\hline $50 / 0$ & 0.15 & $0.22^{\mathrm{ab}}$ & 0.33 & 0.02 & $0.03^{\mathrm{a}}$ & 0.03 \\
\hline $50 / 5$ & 0.16 & $0.29^{b}$ & 0.43 & 0.8 & $1.33^{\mathrm{c}}$ & 0.18 \\
\hline $50 / 10$ & 0.31 & $0.33^{b}$ & 0.39 & 0.96 & $1.08^{\mathrm{bc}}$ & 1.19 \\
\hline $100 / 0$ & 0.21 & $0.27^{b}$ & 0.40 & 0.28 & $0.04^{\mathrm{a}}$ & 0.58 \\
\hline $100 / 5$ & 0.59 & $0.67^{\mathrm{c}}$ & 0.78 & 0.55 & $0.73^{b}$ & 1.02 \\
\hline $100 / 10$ & 0.32 & $0.54^{\mathrm{c}}$ & 0.79 & 0.51 & $0.71^{b}$ & 0.97 \\
\hline
\end{tabular}

Legend: $\mathrm{C}$ - control variant without application of $\mathrm{Pb}$ and EDTA, $\mathrm{x}_{\min }-$ minimum value, $\mathrm{x}_{\max }$ maximum value, $\mathrm{x}_{\mathrm{m}}-$ mean value, ${ }^{a, b, c, d, e}$ - single-factor analysis of variance, Tukey $\mathrm{b}$ test - statistically significant difference is between the mean values which have different index in the same group, significance level $\mathrm{p}<0.05, \mathrm{n}$ (number of duplicates) $=9$. 


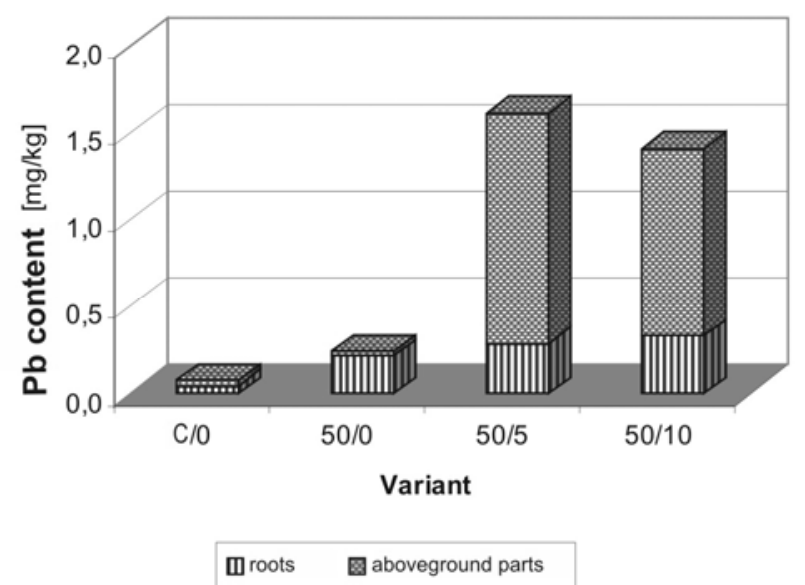

Fig. 1. Transfer of lead to roots and aboveground parts of garden pea in soil with addition $50 \mathrm{mg} \mathrm{Pb} \cdot \mathrm{kg}^{-1}$ in dependence on applied amounts of EDTA (pot experiments in growth chamber, Nitra, 2008)

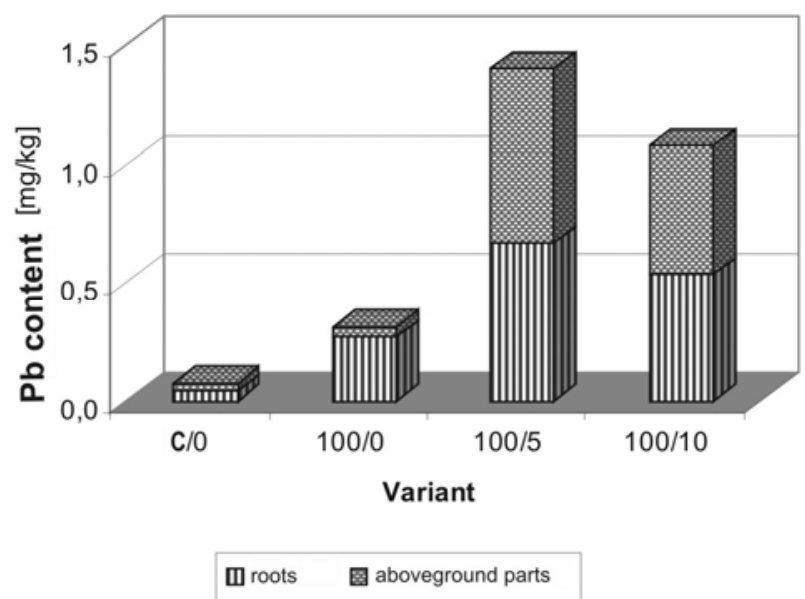

Fig. 2. Transfer of lead to roots and aboveground parts of garden pea in soil with addition $100 \mathrm{mg} \mathrm{Pb} \cdot \mathrm{kg}^{-1}$ in dependence on applied amounts of EDTA (pot experiments in growth chamber, Nitra, 2008)

Many studies dealt with increase of heavy metal accumulation in plants within the process of induced phytoextraction. Result of experiment of HUANG and co-workers (1997) confirmed that application of $1 \mathrm{~g}$ EDTA. $\mathrm{kg}^{-1}$ to soil contamined with $2500 \mathrm{mg}$ $\mathrm{Pb} . \mathrm{kg}^{-1}$ enhanced lead transfer to roots and aboveground plant parts about 120-times. Five synthetic chelating agents (EDTA, HEDTA, DTPA, EGTA, EDDHA) were examined and just EDTA showed the most intensive desorption properties.

\subsection{Biomass production}

The biomass production and content of dry mass was followed in all experimental variants. The results showed the statistically significant difference only in variants 
treated with 10 mmol EDTA.kg ${ }^{-1}$ (Table 2). This amount of chelating agent affected 24 to $33 \%$ decrease of root biomass production (calculations were done with dry mass values). Therefore we also supposed decrease of lead uptake intensity by root system.

Table 2. Dry mass of roots and aboveground plant parts of pea in all variants (pot experiments in growth chamber, Nitra, 2008).

\begin{tabular}{|c|c|c|}
\hline \multirow{2}{*}{$\begin{array}{c}\text { Variant } \\
\text { Pb/EDTA }\end{array}$} & \multicolumn{2}{|c|}{ Dry mass (g/pot) } \\
\hline & roots & aboveground parts \\
\hline $\mathrm{C}$ & $0.73^{\mathrm{a}}$ & $3.33^{\mathrm{a}}$ \\
\hline $50 / 0$ & $0.70^{\mathrm{a}}$ & $3.33^{\mathrm{a}}$ \\
\hline $50 / 5$ & $0.68^{\mathrm{a}}$ & $2.99^{\mathrm{a}}$ \\
\hline $50 / 10$ & $0.53^{b}$ & $3.09^{\mathrm{a}}$ \\
\hline $100 / 0$ & $0.67^{\mathrm{a}}$ & $3.33^{\mathrm{a}}$ \\
\hline $100 / 5$ & $0.57^{\mathrm{a}}$ & $3.33^{\mathrm{a}}$ \\
\hline $100 / 10$ & $0.45^{\mathrm{b}}$ & $2.95^{\mathrm{a}}$ \\
\hline
\end{tabular}

Note: single-factor analysis of variance, Tukey $b$ test $(\mathrm{P}<0.05)$.

\subsection{Transport index- $T_{i}$}

Transport index (Table 3) was calculated as a ratio between $\mathrm{Pb}$ content in aboveground part and its content in root.

Table 3. Transport index.

\begin{tabular}{cc}
\hline Variant & $\mathbf{T i}$ \\
\hline $\mathbf{5 0 / 0}$ & 14.00 \\
$\mathbf{5 0 / 5}$ & 4.59 \\
$\mathbf{5 0 / 1 0}$ & 3.27 \\
$\mathbf{1 0 0 / 0}$ & 0.15 \\
$\mathbf{1 0 0 / 5}$ & 1.09 \\
$\mathbf{1 0 0 / 1 0}$ & 1.31 \\
\hline
\end{tabular}

Note: Ti - Transport index (aboveground parts /roots)

The results showed that concentration of 5 mmol EDTA. $\mathrm{kg}^{-1}$ enhanced $\mathrm{Pb}$ transport from roots to aboveground parts 33-times in variant with $50 \mathrm{mg} \mathrm{Pb} . \mathrm{kg}^{-1}$. Lower transport indexes (1.09 and 1.31) were calculated in variants with addition $100 \mathrm{mg}$ $\mathrm{Pb} . \mathrm{kg}^{-1}$, which were probably connected with decrease of weight of root system.

\subsection{Lead balance in plant}

Lead balance in pea plant showed 56 to $62 \%$ accumulation of the metal in roots in variants without EDTA treatment. Induced phytoextraction was activated after additions 5 and 10 mmol EDTA. $\mathrm{kg}^{-1}$, which resulted in enhanced of the metal mobility 
from roots. Moreover, $95 \%$ and $88 \%$ of metal content was translocated to

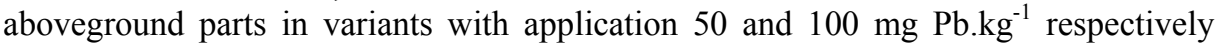
(Table 4).

Table 4. Lead balance in pea plant (pot experiments in growth chamber, Nitra, 2008).

\begin{tabular}{|c|c|c|c|c|}
\hline \multirow{3}{*}{ Variant } & \multicolumn{4}{|c|}{ Withdrawn amount of $\mathrm{Pb} /$ pot/dry mass } \\
\hline & \multicolumn{2}{|c|}{ roots } & \multicolumn{2}{|c|}{ aboveground parts } \\
\hline & {$[\mu \mathrm{g}]$} & {$[\%]$} & {$[\mu \mathrm{g}]$} & [\%] \\
\hline C & 0.03 & 23.07 & 0.10 & 76.93 \\
\hline $50 / 0$ & 0.15 & 62.05 & 0.09 & 37.50 \\
\hline $50 / 5$ & 0.18 & 5.02 & 3.41 & 94.98 \\
\hline $50 / 10$ & 0.18 & 4.78 & 3.59 & 95.22 \\
\hline $100 / 0$ & 0.19 & 55.88 & 0.15 & 44.12 \\
\hline $100 / 5$ & 0.39 & 13.00 & 2.61 & 87.00 \\
\hline $100 / 10$ & 0.27 & 11.74 & 2.03 & 88.26 \\
\hline
\end{tabular}

The lowest transfer of lead from roots to aboveground parts of pea in variant with addition $100 \mathrm{mg} \mathrm{Pb} \cdot \mathrm{kg}^{-1}$ could be caused by lower production of root biomass after application of chelate.

\section{Conclusions}

Despite the fact that in the recent years decreased the amount of emissions in Slovakia as a result of certain system precautions, the problem of heavy metal pollution of the environment still exist. Hygienic safety of agricultural soils was the basic assumption for growth of hygienic safety foodstuffs.

The results from the study of induced phytoextraction process on garden pea plants (Pisum sativum L.) using the chelating agent EDTA allowed us to conclude the following:

1. Content of lead in plants in experimental variants with $\mathrm{Pb}$ addition increased after application of chelating agent. Uptake of lead to aboveground parts of pea increased using EDTA concentrations 5 and 10 mmol EDTA. $\mathrm{kg}^{-1}$ in the range from 36 to 44 fold (in variant with $50 \mathrm{mg} \mathrm{Pb} \cdot \mathrm{kg}^{-1}$ ) and to 18 -fold (in variant with $100 \mathrm{mg} \mathrm{Pb}^{\mathrm{kg}} \mathrm{kg}^{-1}$ ).

2. Statistical significant enhancement of lead transfer from soil to roots was observed only in variant with $100 \mathrm{mg} \cdot \mathrm{kg}^{-1} \mathrm{~Pb}$ addition and present 2 to 2.4 fold increase.

3. Efficiency of $\mathrm{Pb}$ translocation from roots to aboveground parts of pea was evaluated from the calculations of transport indexes. The highest values of transport indexes

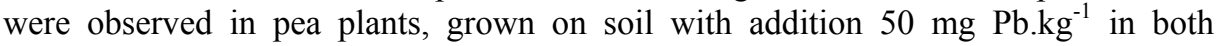
variants treated with EDTA.

4. The balance of lead content showed enhancement of metal mobility from roots after treatment with EDTA. Moreover, $95 \%$ of absorbed metal was translocated to aboveground parts. 
5. Decrease of dry mass production was observed only on root biomass after treatment with 10 mmol EDTA. $\mathrm{kg}^{-1}$, which resulted to decrease of lead uptake from soil.

We can conclude that the most effective continual phytoextraction of lead using garden pea was in variant with $50 \mathrm{mg} P \mathrm{~Pb}^{-1}$ after application 5 mmol EDTA. $\mathrm{kg}^{-1}$. Theoretical calculations showed that garden pea is able to absorb 45-times more lead after chelate treatment than in the case without treatment. Pea biomass could be used as an fuel and lead could be obtained back in metal form. Another manner how to manage with the biomass is composting, which can reduce its volume.

Ackowledgment: The work was supported by the project VEGA 1/4370/07.

\section{References}

FODOR, F.: Ólom és kadmiumstressz növényekben. Bot. Közlem., 90, 2003, 107-120.

FODOR, F., SÁRVÁRI, É., LÁNG, F., SZIGET, Z., CSEH, E.: Effects of Pb and Cd on cucumber depending on the Fe-complex in the culture solution. J. Plant. Physiol., 148, 1996, 434-439.

GRČMAN, H., VODNÍK, D., VELIKONJA-BOLTA, Š., LEŠTAN, D.: Heavy metals in the environment. J. Environ. Qual., 32, 2003, 500-506.

HEGEDÜSOVÁ, A., HEGEDÜS, O., VOLLMANNOVÁ, A.: Kontaminácia pol’nohospodárskych pôd a zelenín t’ažkými kovmi na južnom Slovensku. Hort. Sci., 27, 2000, 57-64.

HUANG, J.W., CUNNINGHAM, S.D.: Lead phytoextraction: Species variation in lead uptake and translocation. New Phytol., 134, 1996, 75-84.

HUANG, J.W., CHEN, J., BERTI, W. R., CUNNINGHAM, S.D.: Phytoremediation of lead-contaminated soils: Role of synthetic chelates in lead phytoextraction. Environ. Sci. Technol., 31, 1997, 800-805.

KAFKA, Z., PUNČOCHÁŘOVÁ, J.: Těžké kovy v prŕrodě a jejich toxicita. Chem. Listy, 96, 2002, $611-617$.

LASAT, M.: Phytoextraction of Toxic Metals. J. Environ. Qual., 31, 2002, 109-120.

LUO, CH., SHEN, Z., LI, X.: Root exudates increase metal accumulation in mixed cultures: Implications for naturally enhanced phytoextraction. Water Air Soil Pollut., 193, 2008, 147 - 154.

MCGRATH, S.P. ZHAO, F.J., LOMBI, E.: Phytoremediation of metals, metalloids, and radionuclides. Adv. Agron., 75, 2002, 1-56.

SIMON, L., SZEGVÁRI, I., CSILLAG J.: Impact of picolinic acid on the chromium accumulation in fodder radish and komatsuna. Plant Soil, 254, 2003, 337-348 